\title{
Regulation of Phosphorylation of the GluR1 AMPA Receptor in the Neostriatum by Dopamine and Psychostimulants In Vivo
}

\author{
Gretchen L. Snyder, ${ }^{1}$ Patrick B. Allen, ${ }^{1}$, Allen A. Fienberg, ${ }^{1}$ Carmina G. Valle, ${ }^{1}$ Richard L. Huganir, ${ }^{2}$ \\ Angus C. Nairn, ${ }^{1}$ and Paul Greengard ${ }^{1}$ \\ ${ }^{1}$ Laboratory of Molecular and Cellular Neuroscience, The Rockefeller University, New York, New York 10021, and \\ 2Department of Neuroscience, Howard Hughes Medical Institute, The Johns Hopkins University School of Medicine, \\ Baltimore, Maryland 21205
}

\begin{abstract}
The activation of cAMP-dependent protein kinase regulates the physiological activity of AMPA-type glutamate receptors. In this study, phosphorylation of the AMPA receptor subunit GluR1 at $\mathrm{Ser}^{845}$ was increased in neostriatal slices by activation of D1type dopamine receptors and by inhibitors of protein phosphatase 1/protein phosphatase 2A. In contrast, $\operatorname{Ser}^{831}$, a residue which, when phosphorylated by protein kinase C or calcium/ calmodulin-dependent kinase II, increases AMPA receptor channel conductance, was unaffected by either D1 or D2 receptor agonists in neostriatal slices. The phosphorylation of
\end{abstract}

$\operatorname{Ser}^{845}$, but not $\operatorname{Ser}^{831}$, was strongly increased in neostriatum in vivo in response to the psychostimulants cocaine and methamphetamine. The effects of dopamine and psychostimulants on the phosphorylation of GluR1 were attenuated in dopamine and cAMP-regulated phosphoprotein $M_{\mathrm{r}} 32 \mathrm{kDa}$ (DARPP-32) knock-out mice. These results identify DARPP-32 and AMPAtype glutamate receptors as likely essential cellular effectors for psychostimulant actions.

Key words: dopamine; DARPP-32; methamphetamine; cocaine; protein phosphatase 1; D1 receptor; protein kinase $A$
Ionotropic glutamate receptors function as ligand-gated ion channels and are believed to play a role in certain forms of learning and memory (Bliss and Collingridge, 1993; Linden, 1994), in the development of psychomotor stimulant sensitization (Wolf, 1998) and in various forms of neurodegenerative disease (Lipton and Rosenberg, 1994). They are classified by their physiological and pharmacological characteristics as members of AMPA, kainate, or NMDA receptor subclasses (Monaghan et al., 1989). AMPAtype glutamate receptors are abundantly expressed on dendritic processes of medium spiny neostriatal neurons (Petralia and Wenthold, 1992) where they mediate a large proportion of the glutamate-induced excitation (Cepeda et al., 1993).

Considerable evidence indicates that AMPA receptors are regulated by protein phosphorylation. For example, activation of cAMP-dependent protein kinase (PKA) in hippocampal (Greengard et al., 1991; Wang et al., 1991; Rosenmund et al., 1994; Kameyama et al., 1998) or neostriatal (Yan et al., 1999) neurons increases AMPA currents recorded from these cells. The notion that these effects occur as the result of phosphorylation of the receptor is supported by the observation that the GluR1 subunit is phosphorylated in response to PKA activation in human embryonic kidney-293 cells (Blackstone et al., 1994; Tan et al., 1994) (but see McGlade-McCulloh et al., 1993). Moreover, a PKAdependent residue, $\mathrm{Ser}^{845}$, is required for PKA-mediated potentiation of peak current carried by homomeric GluR1 channels (Roche et al., 1996). AMPA receptors also can be regulated by phosphorylation of Ser ${ }^{831}$ after activation of calcium/calmodulin-

\footnotetext{
Received Dec. 14, 1999; revised March 1, 2000; accepted April 7, 2000.

This work was supported by United States Public Health Service Grants DA10044 and MH40899 (P.G.). We thank Peter Ingrassia and Stacey Galdi for excellent technical assistance.

Correspondence should be addressed to Dr. Gretchen L. Snyder, Laboratory of Molecular and Cellular Neuroscience, The Rockefeller University, Box 296, 1230 York Avenue, New York, NY 10021. E-mail: snyderg@rockvax.rockefeller.edu. Copyright (C) 2000 Society for Neuroscience $0270-6474 / 00 / 204480-09 \$ 15.00 / 0$
}

dependent kinase II (CaMKII) (Barria et al., 1997) or protein kinase $\mathrm{C}$ (PKC) leading to potentiation of AMPA currents in hippocampal neurons (Barria et al., 1997; Mammen et al., 1997). Whereas PKA-mediated phosphorylation at $\operatorname{Ser}^{845}$ enhances AMPA currents by increasing channel open time probability (Roche et al., 1996), phosphorylation at Ser $^{831}$ increases singlechannel conductance of AMPA receptors (Derkach et al., 1999). Thus, PKA and CaMKII/PKC signaling cascades control distinct properties of the AMPA receptor by regulating unique GluR1 residues.

Dopamine and cAMP-regulated phosphoprotein $M_{\mathrm{r}} 32 \mathrm{kDa}$ (DARPP-32); is a neostriatum-enriched substrate for PKA (Walaas et al., 1983; Ouimet et al., 1984). Phosphorylation at $\mathrm{Thr}^{34}$ by PKA converts DARPP-32 into an efficient inhibitor of protein phosphatase 1 (PP1) (Hemmings et al., 1984), a serine/threonine phosphatase enriched in the dendritic spines of neostriatal neurons (Ouimet et al., 1995). Studies using mice lacking the gene for DARPP-32 indicate that DARPP-32 mediates many physiological and behavioral effects of dopamine (Fienberg et al., 1998). A recent study (Yan et al., 1999) showed that whole-cell AMPA currents are enhanced by D1 dopamine receptors via a pathway involving DARPP-32, PP1, and the PP1-targeting protein spinophilin (Allen et al., 1997). A principal goal of the present study was to determine whether regulation of neostriatal GluR1 subunit phosphorylation by this pathway is a plausible mechanism for the physiological control of AMPA receptors by dopamine.

Psychostimulants increase the synaptic availability of dopamine in the brain (Hyman, 1996; Koob and LeMoal, 1997), leading to both acute and long-term plastic changes in dopaminoceptive neurons (Nestler and Aghajanian, 1997). Some of these effects appear to require the activation of glutamate receptors, although the precise role that glutamate plays in addiction is unclear (Wolf, 1998). Thus, a second objective of this study was to investigate the 
A.
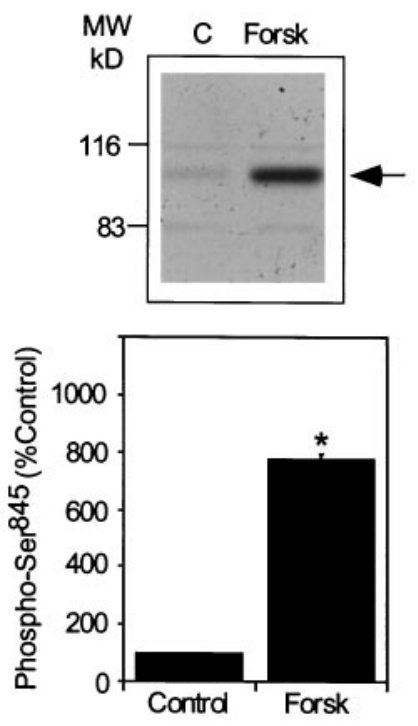

B.

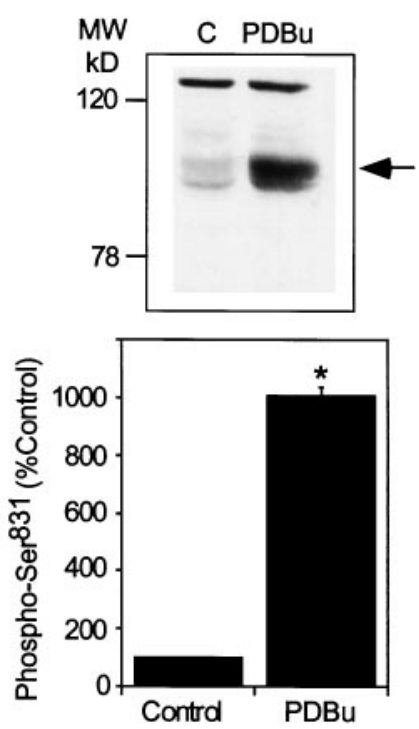

Figure 1. Effects of protein kinase activators on GluR1 phosphorylation in neostriatal slices. Neostriatal slices were prepared from normal C57BL/6 mice and incubated for $5 \mathrm{~min}$ in the absence (Control) or presence of the adenylyl cyclase activator forskolin $(A)$ or the PKC activator PDBu $(B)$. Levels of phospho-Ser ${ }^{845}(A)$ or phospho-Ser ${ }^{831}(B)$ were determined by SDS-PAGE and immunoblotting. Phospho-GluR1 levels were detected, quantitated by densitometry, and expressed as percentage of the level detected in control slices. Arrows (top panels) indicate the position of the phospho-GluR1 bands in representative autoradiograms. Data (bottom panels) are expressed as means \pm SEM for three experiments ( ${ }^{*} p<0.05$ compared with control, Mann-Whitney $U$ test).

possibility that regulation of AMPA receptor phosphorylation in vivo by psychostimulants might contribute to these effects.

\section{MATERIALS AND METHODS}

Preparation and treatment of neostriatal slices. Male C57BL/6 mice (8-12 weeks in age) were killed by decapitation. The brain was rapidly transferred to an ice-cold surface where it was blocked and fixed to the cutting surface of a Vibratome (Ted Pella) maintained at $4^{\circ} \mathrm{C}$. The brain was placed in cold, oxygenated $\left(95 \% \mathrm{O}_{2}\right.$ and $\left.5 \% \mathrm{CO}_{2}\right)$ Krebs' bicarbonate buffer of the following composition (in $\mathrm{mM}$ ): $125 \mathrm{NaCl}, 5 \mathrm{KCl}, 26$ $\mathrm{NaHCO}_{3}, 1.5 \mathrm{CaCl}_{2}, 1.5 \mathrm{MgSO}_{4}$, and 10 glucose, $\mathrm{pH}$ 7.4. Coronal slices of mouse brain ( $400 \mu \mathrm{m}$ in thickness) were cut and pooled in $10 \mathrm{ml}$ of cold buffer. Neostriatal slices were cut from the coronal sections under a dissecting microscope. The slices were pooled, then transferred individually to $4 \mathrm{ml}$ polypropylene tubes containing $2 \mathrm{ml}$ of fresh, cold, oxygenated buffer. The tissue was preincubated for $15 \mathrm{~min}$ at $30^{\circ} \mathrm{C}$, the buffer was replaced, and tissue sections were preincubated for an additional 30 min. At the end of this second preincubation period, the buffer was replaced with Krebs' buffer or buffer containing the indicated test substances for $30 \mathrm{sec}$ to $60 \mathrm{~min}$. After treatment, the slices were immediately frozen in liquid nitrogen and stored at $-80^{\circ} \mathrm{C}$ until assayed.

In some experiments, neostriatal slices were prepared from C57BL/6 mice (8-10 weeks of age) lacking the gene for DARPP-32 (Fienberg et al., 1998). DARPP-32 knock-out mice and wild-type controls were generated from the offspring of heterozygous mating pairs. All mice were age-matched, and only males were used.

Preparation of GluR1 fusion protein for stoichiometric analysis of $\mathrm{Ser}^{845}$ and Ser ${ }^{831}$ phosphorylation. A bacterial protein comprising the last putative intracellular domain of GluR1 (residues 809-889) fused to glutathione- $S$-transferase (GST) was prepared as follows: rat brain cDNA was used as a template for PCR amplification of the GluR1 sequence using the primers TGC GTC GAC CGA GTT CTG CTA CAA ATC CC; TTC GCG GCC GCT CCA GTT ACA ATC CTG TG (Operon). The resulting 272 bp fragment was digested with SalI-NotI and ligated in frame with the GST coding sequence contained in a
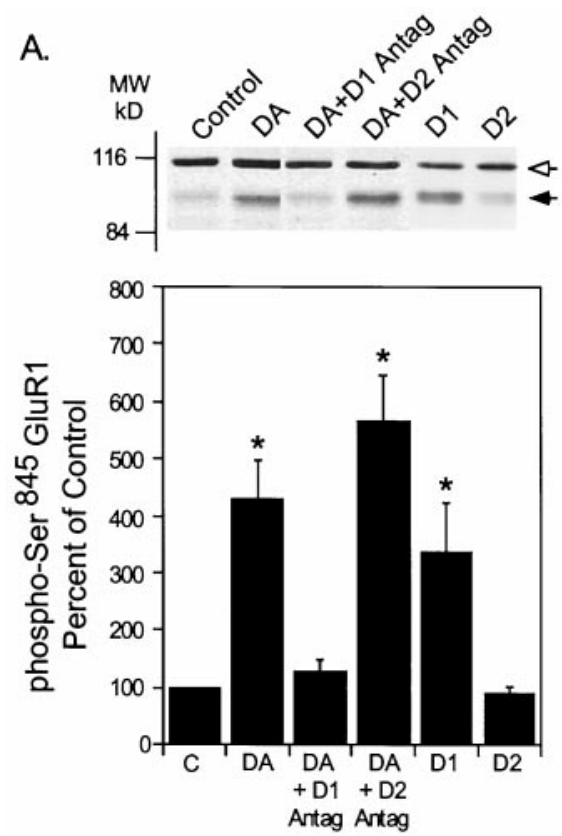

B.

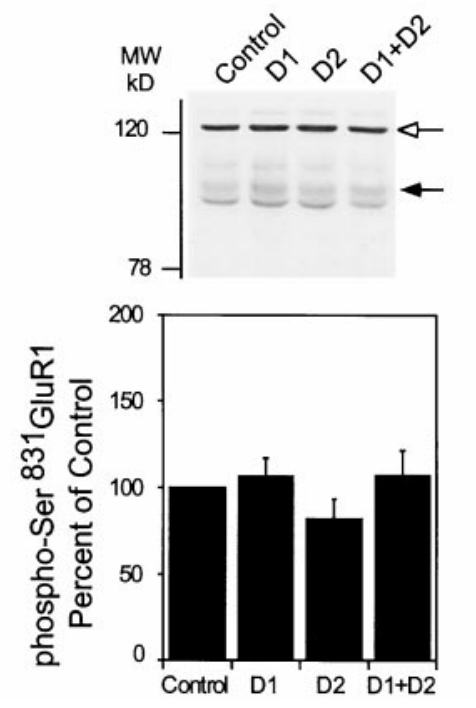

Figure 2. Effect of activation of D1-type or D2-type dopamine receptors on neostriatal GluR1 phosphorylation. Neostriatal slices were prepared from normal $\mathrm{C} 57 \mathrm{BL} / 6$ mice. $A$, At time 0 slices were incubated in the absence or presence of the D1 receptor antagonist SCH23390 (1 $\mu \mathrm{M}$; D1 Antag) or the D2 receptor antagonist sulpiride (1 $\mu \mathrm{M}$; D2 Antag), as indicated. At $10 \mathrm{~min}$ slices were incubated in normal buffer alone (Control $)$, with dopamine $(D A)(100 \mu \mathrm{M})$ plus the dopamine uptake inhibitor nomifensine $(10 \mu \mathrm{M})$, SKF81297 $(1 \mu \mathrm{M})$ (D1) or quinpirole $(1 \mu \mathrm{M})(\mathrm{D} 2)$, with or without $\mathrm{SCH} 23390$ or sulpiride for an additional $5 \mathrm{~min}$. B, Slices were incubated with either normal buffer (Control) or with SKF81297 (1 $\mu \mathrm{M})$ or quinpirole $(1 \mu \mathrm{M})$ for $5 \mathrm{~min}$. The solid arrows indicate the position of phospho-Ser ${ }^{845}$ GluR1 $(A)$ or phospho-Ser ${ }^{831}$ GluR1 $(B)$. The open arrows indicate cross-reactive bands detected by the phosphorylation state-specific antibody. The intensity of these bands did not change as a function of dopamine agonist or antagonist treatment. Phospho-Ser ${ }^{845}$ GluR1 $(A)$ or phospho-Ser ${ }^{831}$ GluR1 $(B)$ was detected in the samples, quantitated by densitometry, and expressed as percentage of the level in control slices. Data are presented as means \pm SEM for three experiments ( ${ }^{*} p<0.05$ compared with control, Mann-Whitney $U$ test).

bacterial expression plasmid pGex-4T-2 (Pharmacia, Piscataway, NJ). This plasmid was sequenced to ensure fidelity of PCR amplification and transformed into Escherichia coli strain BL21 DE3. Bacteria were grown at $37^{\circ} \mathrm{C}$ to an $\mathrm{OD}_{600}$ of 0.5 . The temperature was reduced to $30^{\circ} \mathrm{C}$, and 
expression was induced over $2 \mathrm{hr}$ by the addition of isopropylthio- $\beta$ galactoside to a final concentration of $0.1 \mathrm{~mm}$. Cells were harvested by centrifugation and lysed in a French press. After clarification of the lysate by centrif ugation at $30,000 \times g$ for $20 \mathrm{~min}$, the fusion protein was purified by affinity chromatography on glutathione-agarose beads (Pharmacia), using $5 \mathrm{~mm}$ glutathione and $50 \mathrm{~mm}$ Tris, $\mathrm{pH}$ 8.0, for elution.

GST-GluR1 $(35 \mu \mathrm{M})$ was preparatively phosphorylated under the following conditions: $10 \mu \mathrm{g} / \mathrm{ml}$ purified PKA in $50 \mathrm{~mm}$ Tris, $\mathrm{pH} 8.0,10$ mM magnesium chloride, $0.4 \mathrm{~mm}$ EGTA, $50 \mu \mathrm{M}\left[\gamma^{32} \mathrm{P}\right]$ ATP or $1 \mu \mathrm{g} / \mathrm{ml}$ purified CaMKII in $50 \mathrm{~mm}$ Tris, $\mathrm{pH} 8.0,10 \mathrm{~mm}$ magnesium chloride, 0.4 mM EGTA, 2 mM DTT, $1 \mu \mathrm{M}$ calmodulin, $1.5 \mathrm{~mm}$ calcium chloride, and $50 \mu \mathrm{M}\left[\gamma^{32} \mathrm{P}\right]$ ATP. Reactions were stopped by the addition of Laemmli buffer. Stoichiometry of the phosphorylated fusion proteins was calculated based on PhosphorImager (Molecular Dynamics, Eugene, OR) analysis of phosphate incorporation. Known quantities of these proteins were compared with tissue samples, the levels of phospho-GluR1 and GluR1 were detected by ECL, and the resulting values used to calculate stoichiometries of phosphorylation for the Ser ${ }^{845}$ and $\operatorname{Ser}^{831}$ sites in neostriatal tissue.

Drug treatment and microwave irradiation of mice. Male C57BL/6 mice (8-12 weeks in age) were injected with vehicle $(0.9 \% \mathrm{NaCl}$ in water) or vehicle containing various concentrations of either methamphetamine $\mathrm{HCl}(20$ or $30 \mathrm{mg} / \mathrm{kg}$, s.c.) or cocaine $\mathrm{HCl}$ (10 or $20 \mathrm{mg} / \mathrm{kg}$, i.p.). To insure preservation of phosphoproteins in their in vivo phosphorylation state, the animals were killed at various times (15-60 $\mathrm{min})$ after injection by focused microwave irradiation $(4.5-5 \mathrm{~kW}$ for $1.4 \mathrm{sec})$ using a smallanimal microwave (Murimachi Kikai, Tokyo, Japan). The brains were rapidly removed, and the neostriatum was dissected and stored at $-80^{\circ} \mathrm{C}$ until assayed for phosphoprotein levels.

Immunoblotting for phospho-GluR1. Frozen tissue samples were sonicated in $1 \%$ SDS. Small aliquots of the homogenate were retained for protein determination by the BCA protein assay method (Pierce, Rockford, IL) using bovine serum albumin as a standard. Equal amounts of protein (50 $\mu \mathrm{g}$ for slice experiments; $250 \mu \mathrm{g}$ for microwave experiments) were loaded onto $7.5 \%$ acrylamide gels. The proteins were separated by SDS-PAGE (Laemmli, 1970), and transferred to nitrocellulose membranes $(0.2 \mu \mathrm{m})$ (Schleicher and Schuell) by the method of Towbin et al. (1979). Membranes were blocked for 30-60 min in PBS (in mM: 124 $\mathrm{NaCl}, 4 \mathrm{KCl}, 10 \mathrm{Na}_{2} \mathrm{HPO}_{4}$, and $10 \mathrm{KH}_{2} \mathrm{PO}_{4}, \mathrm{pH} 7.2$ ) containing $5 \%$ nonfat dry milk and $0.2 \%$ Tween 20 (Blotto). The membranes were immunoblotted using antisera that selectively detect either the $\operatorname{Ser}^{845}$ phosphorylated or the Ser ${ }^{831}$-phosphorylated form of GluR1 (1:200 dilutions for each antibody) (Kameyama et al., 1998), or an antiserum (PharMingen, San Diego, CA; 1:10,000 dilution) that detects the C-terminal region of GluR1, irrespective of phosphorylation state. In some experiments these samples were also immunoblotted with monoclonal antibody 23 (1:750 dilution) (Snyder et al., 1992), a phosphorylation state-specific monoclonal antibody raised against a DARPP-32 peptide containing phospho- $\mathrm{Thr}^{34}$, the site phosphorylated by PKA.

Antibody binding was revealed by incubation with either a goat antirabbit horseradish peroxidase-linked IgG or a goat anti-mouse horseradish peroxidase-linked IgG (each at a 1:6000-8000 dilution) (Pierce) and the ECL immunoblotting detection system (Amersham, Arlington Heights, IL). Chemiluminescence was detected by autoradiography using DuPont NEN (Boston, MA) autoradiography film, and bands were quantified by analysis of scanned images by NIH Image 1.52 software. Because the linear range for quantitation of ECL signals by densitometry is limited, several film exposures were obtained for each set of samples to insure that signals were within a density range that allowed accurate quantitation.

In all of the experiments for this study, nitrocellulose membranes were sequentially analyzed for phospho-Ser ${ }^{845}$ GluR1 or for phospho-Ser ${ }^{831}$ GluR1, and then for total levels of C-terminal GluR1. After probing a membrane for phospho-GluR1, the filter was washed three times for 5 min each in PBS to remove any remaining chemiluminescent reagent. The membrane was then stripped of antibody by incubation at $60^{\circ} \mathrm{C}$ for $60 \mathrm{~min}$ in a buffer containing $100 \mathrm{~mm}$ 2-mercaptoethanol, $2 \%$ SDS, and $62.5 \mathrm{~mm}$ Tris/ $\mathrm{HCl}, \mathrm{pH}$ 6.7. The filter was then washed several times in large volumes of PBS and blocked in Blotto for 30-60 min before immunoblotting with the C-terminal GluR1 antibody.

Data were analyzed by Student's $t$-test or Mann-Whitney $U$ test, as indicated, with significance defined as $p<0.05$.



\section{B. Ser831}

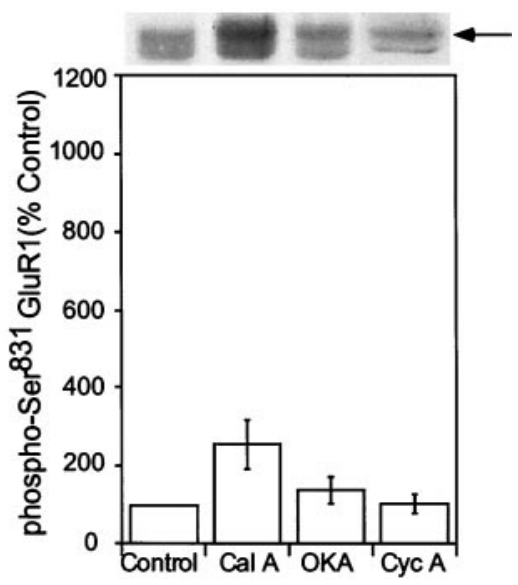

Figure 3. Effects of protein phosphatase inhibitors on the phosphorylation state of neostriatal GluR1 at $\operatorname{Ser}^{845}$ and $\operatorname{Ser}^{831}$. Mouse neostriatal slices were incubated for $60 \mathrm{~min}$ in the absence (Control) or presence of either okadaic acid $(1 \mu \mathrm{M})(O K A)$ or calyculin $\mathrm{A}(0.5 \mu \mathrm{M})(\mathrm{Cal} A)$, inhibitors of PP1/PP2A, or cyclosporin A $(5 \mu \mathrm{M})(C y c A)$, an inhibitor of PP2B. Ser ${ }^{845}$ phospho-GluR1 $(A)$ and $\operatorname{Ser}^{831}$ phospho-GluR1 $(B)$ were detected, quantitated by densitometry, and expressed as percentage of the level in control slices. Data are expressed as means \pm SEM for three experiments $\left({ }^{*} p<0.05\right.$ compared with control, Mann-Whitney $U$ test).

\section{RESULTS}

\section{Differential phosphorylation of GluR1 in neostriatum by protein kinase activators}

GluR1 is phosphorylated in vitro at $\mathrm{Ser}^{845}$ by PKA (Blackstone et al., 1994) and at Ser $^{831}$ by PKC (Mammen et al., 1997) or CaMKII (McGlade-McCulloh et al., 1993). Phosphorylation of GluR1 at $\mathrm{Ser}^{845}$, in response to activation of PKA, potentiates AMPA currents by increasing open time probability of the receptor channel (Roche et al., 1996). The phosphorylation of GluR1 at Ser $^{831}$ in response to activation of CaMKII or PKC increases AMPA receptor function by enhancing channel conductance (Derkach et al., 1999). Treatment of neostriatal slices with forskolin $(50 \mu \mathrm{M})$, an adenylyl cyclase activator, increased phosphorylation of Ser $^{845}$ approximately eightfold $(776 \pm 20 \%$ of control in three experiments) (Fig. $1 A$ ). The PKC activator phorbol 12,13-dibutyrate (PDBu) $(5 \mu \mathrm{M})$ (Fig. $1 B)$ increased the phosphorylation of GluR1 at Ser $^{831}$ by an average of 10 -fold $(1005 \pm 28 \%$ of control in three experiments $)$ in neostriatal slices. 
A.

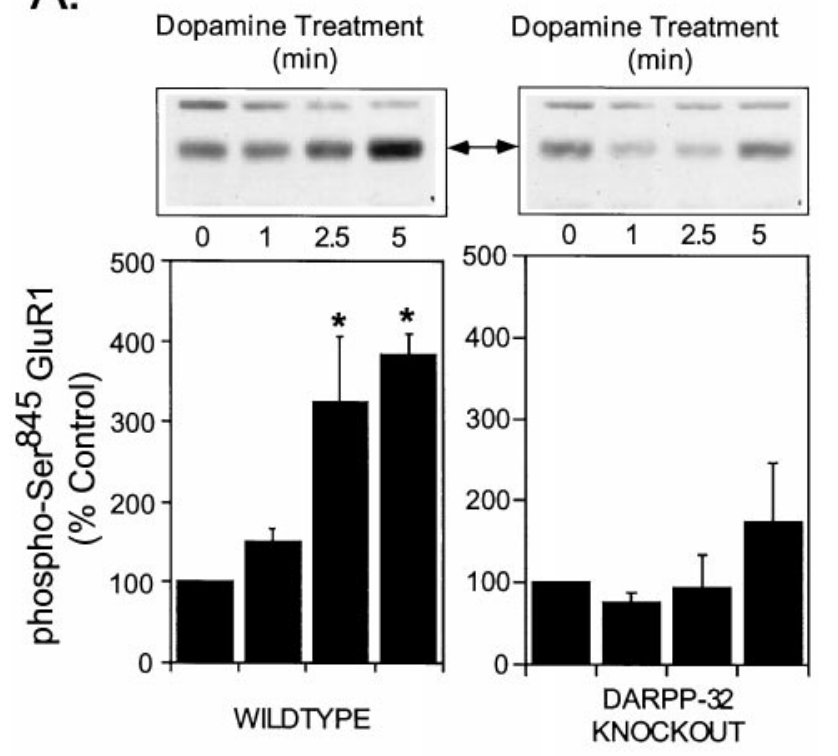

B.

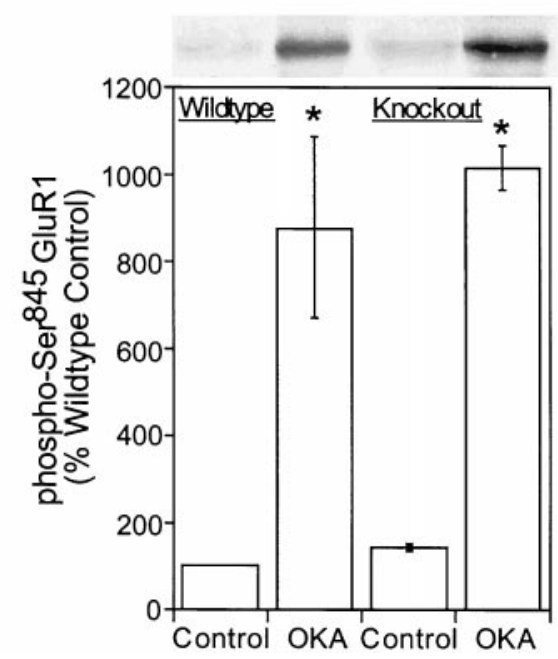

Figure 4. Role of DARPP-32 in the dopamine-induced phosphorylation of neostriatal GluR1 on $\operatorname{Ser}^{845}$. A, Mouse neostriatal slices prepared from wild-type mice (left) or DARPP-32 knock-out mice (right) were incubated in the absence or presence of dopamine $(100 \mu \mathrm{M})$ plus nomifensine $(10$ $\mu \mathrm{M})$ for the indicated times. Samples were immunoblotted for $\mathrm{Ser}^{845}$ phosphorylated GluR1. The level of phospho-GluR1 was quantitated by densitometry, and the data were expressed as percentage of either the wild-type or knock-out control level. The results are expressed as means \pm SEM for five experiments $\left({ }^{*} p<0.05\right.$ compared with 0 time, MannWhitney $U$ test). $B$, Slices from wild-type or knock-out mice were incubated with a maximally effective concentration of the PP1/2A inhibitor, okadaic acid $(O K A ; 1 \mu \mathrm{M})$ for $60 \mathrm{~min}$. The level of phospho-Ser ${ }^{845}$ GluR1 was quantitated by densitometry, and the data were expressed as percentage of the wild-type control level. Results are expressed as means \pm SEM for three experiments $(* p<0.05$ compared with control, Mann-Whitney $U$ test).

Phosphorylation state-specific antibodies were used to compare the levels of phospho-Ser ${ }^{845}$ and phospho-Ser ${ }^{831}$ GluR1 in neostriatal slices with known quantities of GluR1 fusion proteins phosphorylated by PKA or CaMKII, respectively. A low, basal stoichiometry of phosphorylation at $\operatorname{Ser}^{845}$ was measured $(\sim 0.05$ $\mathrm{mol} / \mathrm{mol})$ in slices, which was increased to $\sim 0.33 \mathrm{~mol} / \mathrm{mol}$ after 5 min of forskolin treatment $(50 \mu \mathrm{M})$. Ser ${ }^{831}$ was also phosphory- lated at a low level in untreated slices (a stoichiometry of 0.06 $\mathrm{mol} / \mathrm{mol})$. The stoichiometry of phosphorylation at $\operatorname{Ser}^{831}$ was increased to $\sim 0.26 \mathrm{~mol} / \mathrm{mol}$ after $5 \mathrm{~min}$ of $\mathrm{PDBu}$ treatment (5 $\mu \mathrm{M})$. These data indicate that GluR1 is phosphorylated in intact neostriatal cells at $\mathrm{Ser}^{845}$ or Ser ${ }^{831}$, after activation of either PKA or PKC/CaMKII, respectively.

\section{Phosphorylation of GluR1 in response to dopamine receptor stimulation}

Dopamine receptors are subdivided into a D1 class (i.e., D1, D5 subtype receptors) and a D2 class (i.e., D2, D3, and D4 subtype receptors) with the D1 and D2 subtypes being the most highly enriched in mammalian neostriatum (Sibley and Monsma, 1992). D1 class receptors stimulate adenylyl cyclase and increase cAMP formation (Stoof and Kebabian, 1981). D2 class receptors, via interactions with specific G-proteins, can be coupled to multiple effector systems, including adenylyl cyclase, $\mathrm{Ca}^{2+}$ and $\mathrm{K}^{+}$channels, and phospholipase C (Huff, 1996). To evaluate the potential contribution of D1-subtype and D2-subtype dopamine receptors to the regulation of GluR1 phosphorylation, we measured the effects of dopamine and selective D1 and D2 agonists and antagonists on phosphorylation at $\operatorname{Ser}^{845}$ and $\operatorname{Ser}^{831}$.

Dopamine increased the phosphorylation of GluR1 at Ser ${ }^{845}$ (428 $\pm 68 \%$ compared with control) (Fig. $2 A$ ). Levels of phosphorylation were maximal at between 2.5 and $5 \mathrm{~min}$, and declined to basal values by $10 \mathrm{~min}$ of incubation with dopamine (data not shown). The effect of dopamine was blocked by pretreatment of slices with a D1-type receptor antagonist, SCH23390 (1 $\mu \mathrm{M})(127$ $\pm 21 \%$ compared with control). In contrast, the D2-type receptor antagonist sulpiride $(1 \mu \mathrm{M})$ had no effect on dopamine-stimulated phosphorylation of GluR1 (565 $\pm 81 \%$ compared with control) or on D1 agonist-induced phosphorylation of GluR1 (data not shown). Neither the D1 nor the D2 antagonist alone had a significant effect on the basal level of GluR1 phosphorylation (data not shown) indicating that any endogenously released dopamine was not exerting a significant regulation of this site. The phosphorylation of $\operatorname{Ser}^{845}$ was increased by treatment of slices with SKF81297, a D1 agonist (337 $\pm 82 \%$ of control; Fig. $2 A)$, whereas quinpirole, a D2 agonist, had no effect on basal levels (91 $\pm 12 \%$ of control; Fig. $2 A$ ). Quinpirole did not reduce phosphorylation of $\operatorname{Ser}^{845}$ induced by a D1 agonist (data not shown). These data indicate that dopamine-induced phosphorylation of GluR1 is most likely mediated by activation of a D1-receptor/PKAdependent signaling pathway.

D2 agonists have recently been shown to increase intracellular $\mathrm{Ca}^{2+}$ levels in dissociated neostriatal cells (Hernandez et al., 1999), an effect that could result in activation of $\mathrm{Ca}^{2+}$-dependent kinases such as CaMKII. Thus, we evaluated the effects of D1 and D2 receptor activation on Ser ${ }^{831}$ phosphorylation. In contrast to the robust increase in phosphorylation of $\operatorname{Ser}^{845}$ observed in response to dopamine or a D1-selective agonist (Fig. $2 A$ ), neither dopamine, SKF81297 (106 $\pm 11 \%$ of control), quinpirole (82 \pm $12 \%$ of control), nor SKF81297 plus quinpirole $(107 \pm 15 \%$ of control) had a significant effect on $\mathrm{Ser}^{831}$ phosphorylation (Fig. 2B).

\section{Regulation of Ser ${ }^{845}$ phosphorylation: involvement of a DARPP-32/PP1 cascade}

The ability of serine/threonine protein phosphatases to regulate the basal phosphorylation of GluR1 in neostriatal cells was examined. Neostriatal slices were incubated with either calyculin A (500 nM) or okadaic acid $(1 \mu \mathrm{M})$, inhibitors of both PP1 and 
Figure 5. Effect of acute cocaine on neostriatal GluR1 phosphorylation at $\mathrm{Ser}^{845}$ and $\mathrm{Ser}^{831}$ in vivo. Normal C57Bl/6 mice were injected (intraperitoneally) with vehicle alone (Saline) or with vehicle containing cocaine $(20 \mathrm{mg}$ / $\mathrm{kg}$ ) and killed by focused microwave irradiation at 15,30 , or $60 \mathrm{~min}$ after injection. Neostriatum was dissected from each brain and analyzed for phospho-Ser $^{845}$ and phospho-Ser ${ }^{831}$ GluR1. The arrows indicate the position of GluR1, as verified by immunoblotting with an antibody against a C-terminal sequence of GluR1. A, Representative experiment showing immunoblots of phospho-Ser ${ }^{845}$ GluR1 from three individual animals for each treatment condition. B, Quantitation of phospho-Ser $^{845}$ and phospho-Ser ${ }^{831}$ in three experiments, each analyzed in triplicate ${ }^{*} p<0.05$, compared with saline; Mann-Whitney $U$ test).
A.

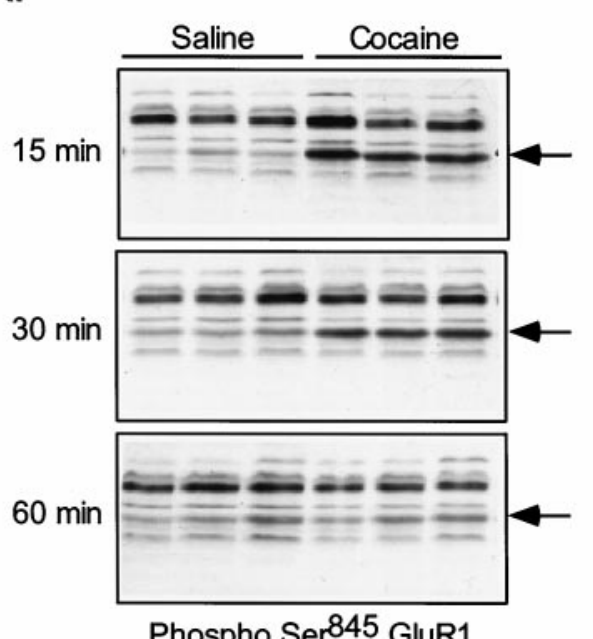

Phospho Ser 845 GluR1
B.

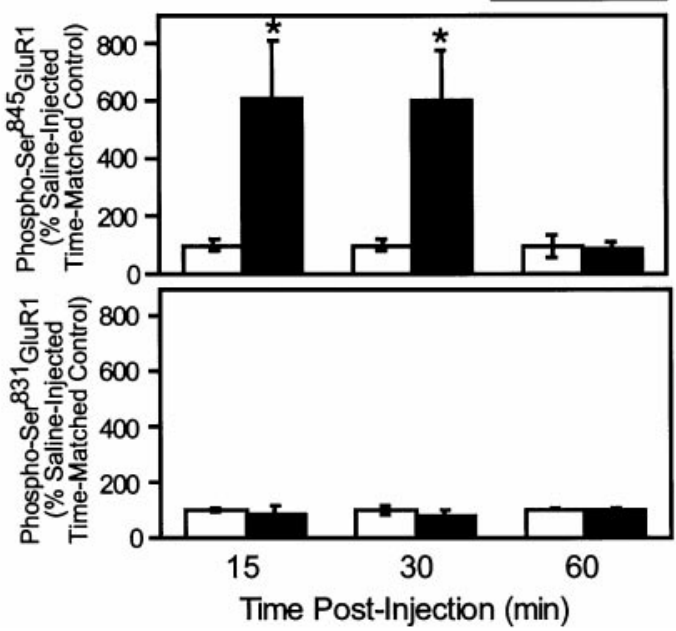

protein phosphatase 2A (PP2A). Calyculin A increased phosphoSer ${ }^{845}$ GluR1 to a level $600 \pm 129 \%$ of control after $60 \mathrm{~min}$ of incubation (Fig. $3 A$ ). Similarly, okadaic acid increased phosphoSer $^{845}$ GluR1 to a maximal level of $783 \pm 102 \%$ of control after 60 min. By comparison, cyclosporin A, an inhibitor of calcineurin (protein phosphatase $2 \mathrm{~B}, \mathrm{PP} 2 \mathrm{~B}$ ), had no significant effect on the basal level of phosphorylated $\operatorname{Ser}^{845}$ GluR1 after a 60 min incubation period (104 $\pm 4 \%$ compared with control; Fig. $3 A$ ) or on the state of phosphorylation of DARPP-32 at $\mathrm{Thr}^{34}$ (data not shown). Phosphorylation of GluR1 at Ser ${ }^{831}$ was slightly increased by calyculin A $(256 \pm 78 \%$ of control $)$ in contrast to the absence of effect of okadaic acid $(137 \pm 36 \%$ of control $)$ or cyclosporin A $(104 \pm 25 \%$ of control) (Fig. $3 B)$. However, the effect of calyculin A was not statistically significant $(p>0.05$; Mann-Whitney $U$ test, for three experiments). These data indicate that $\operatorname{Ser}^{845}$ is a better substrate than $\operatorname{Ser}^{831}$ for regulation by PP1 and/or PP2A in neostriatal neurons.

To investigate the specific contribution of PP1 to dopamineinduced phosphorylation of GluR1, we compared Ser ${ }^{845}$ phosphorylation in wild-type mice and in mice bearing a targeted deletion of the gene for the selective PP1 inhibitor DARPP-32 (Fienberg et al., 1998). These experiments revealed that there was no significant difference in the basal phosphorylation of $\mathrm{Ser}^{845}$ as the result of the DARPP-32 knock-out. Dopamine $(100 \mu \mathrm{M})$ induced a threefold to fourfold increase in phosphorylation of GluR1 at $\operatorname{Ser}^{845}$ in neostriatal slices from wild-type mice (324 \pm $85 \%$ of control at $2.5 \mathrm{~min}$ and $383 \pm 26 \%$ of control at $5 \mathrm{~min}$ ), but not from DARPP-32 knock-out mice $(94 \pm 41 \%$ of control at 2.5 min and $174 \pm 72 \%$ of control at 5 min; Fig. $4 A$ ). A similar attenuation of dopamine-induced phosphorylation was observed in nucleus accumbens slices (data not shown). These data indicate that inhibition of PP1 is required for dopamine-induced increases in GluR1 phosphorylation. In support of this conclusion, we found that direct, pharmacological inhibition of PP1/PP2A affected GluR1 phosphorylation comparably in wild-type and knock-out slices. In this series of experiments okadaic acid increased Ser $^{845}$ phosphorylation in slices from both wild-type and DARPP-32 knock-out mice ( $878 \pm 210 \%$ of control in wild-type mice and $1008 \pm 50 \%$ of control in knock-out mice) after $60 \mathrm{~min}$ of incubation (Fig. 4B).

\section{Regulation of GluR1 phosphorylation by cocaine in vivo}

To evaluate the possible involvement of psychostimulants in the control of AMPA receptor phosphorylation in vivo, intact mice were treated with drugs that are known to enhance dopamine availability in the neostriatum, and the effect on the phosphorylation of GluR1 was examined. We first measured the effect of cocaine $(20 \mathrm{mg} / \mathrm{kg}$, i.p.), a drug that increases dopamine availability through blockade of the dopamine transporter, on the phosphorylation of GluR1 at Ser ${ }^{845}$. Cocaine administration produced a behavioral activation in mice characterized by increased locomotor behavior that was evident within $15 \mathrm{~min}$ of injection. Cocaine also caused a large increase in the phosphorylation state of GluR1 at $\operatorname{Ser}^{845}$ in neostriatum, as observed $15 \mathrm{~min}$ (saline, $100 \pm 18 \%$; cocaine, $612 \pm 198 \%$ ) and $30 \mathrm{~min}$ (saline, $100 \pm 22 \%$; cocaine, $604 \pm 170 \%$ ) after injection (Fig. 5). The effect of cocaine treatment on GluR1 phosphorylation rapidly dissipated, as $\operatorname{Ser}^{845}$ phosphorylation returned to the basal level within 60 min (saline, $100 \pm 4 \%$; cocaine, $89 \pm 25 \%$ ) of drug administration (Fig. 5). In contrast, cocaine treatment did not significantly affect the level of phosphorylation of GluR1 at Ser ${ }^{831}$ in neostriatum compared with time-matched saline-injected controls at any time point examined $(89 \pm 30 \%$ of control at $15 \mathrm{~min} ; 80 \pm 18 \%$ of control at $30 \mathrm{~min}$; and $98 \pm 8 \%$ of control at $60 \mathrm{~min}$ ) (Fig. 5). These data indicate that acute cocaine injection selectively regulates phosphorylation of GluR1 at Ser ${ }^{845}$.

\section{Role of DARPP-32 in cocaine-mediated regulation of Ser $^{845}$ phosphorylation in vivo}

It seemed possible that cocaine-stimulated dopamine release could increase GluR1 phosphorylation by at least two mechanisms. First, dopamine and D1-receptor-mediated activation of PKA would be expected to lead directly to phosphorylation of Ser $^{845}$. Second, PKA-mediated phosphorylation of DARPP-32 at $\mathrm{Thr}^{34}$ would be expected to inhibit PP1 activity, leading to an increase in phosphorylation state of PP1 substrates, including GluR1. Consistent with this idea, cocaine did induce a severalfold increase in phospho-Thr ${ }^{34}$ DARPP-32 (605 $\pm 205 \%$ of control) (Fig. 6A), concurrent with the increase in $\operatorname{Ser}^{845}$ phosphorylation in wild-type mice. A possible role for DARPP-32 in the in vivo 


\section{A. $10 \mathrm{mg} / \mathrm{kg}$ cocaine}

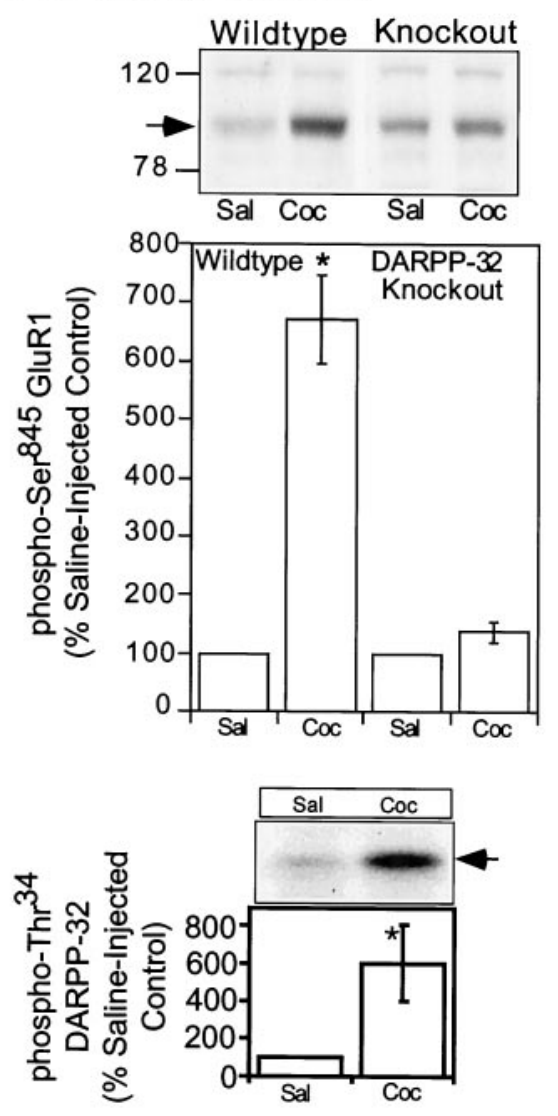

B. $20 \mathrm{mg} / \mathrm{kg}$ cocaine



Figure 6. Effect of acute cocaine on in vivo phosphorylation of GluR1 at $\mathrm{Ser}^{845}$ : comparison of wild-type and DARPP-32 knock-out mice. Wildtype or DARPP-32 knock-out mice were injected (intraperitoneally) with saline vehicle $(\mathrm{Sal})$ or with $(10 \mathrm{mg} / \mathrm{kg})(A)$ or $(20 \mathrm{mg} / \mathrm{kg})(B)$ cocaine $(C O C)$ and killed by focused microwave irradiation $30 \mathrm{~min}$ later. The levels of phospho-Ser ${ }^{845}$ GluR1 and phospho-Thr ${ }^{34}$ DARPP-32 were detected in neostriatum by immunoblotting, and the data were quantitated by densitometry. Arrows indicate the position of phospho-GluR1 and phospho-DARPP-32 bands. A, Top, An autoradiogram of a representative experiment shows the level of phospho-GluR1 in saline-injected or cocaine-injected wild-type and DARPP-32 knock-out mice. The bar graph summarizes phospho-Ser ${ }^{845}$ GluR1 levels in the neostriatum of the wild-type and knock-out mice. Data are expressed as means \pm SEM for phosphorylation of GluR1 was further evaluated by measuring cocaine-induced GluR1 phosphorylation in DARPP-32 knockout mice. The level of GluR1 expressed in neostriatum was unaffected by the genetic deletion of DARPP-32 (data not shown). However, the increase in GluR1 phosphorylation at $\operatorname{Ser}^{845}$ in neostriatum observed after treatment with a low dose of cocaine $(10 \mathrm{mg} / \mathrm{kg}$, i.p.) $(671 \pm 75 \%$ of control in this series of experiments) was greatly attenuated in mice lacking DARPP-32 $(138 \pm 18 \%$ of control; Fig. $6 A)$.

A previous report from this laboratory (Fienberg et al., 1998) showed that the effect of DARPP-32 knock-out on cocaineinduced locomotor behavior was dose-dependent. Thus, the increase in locomotor behavior elicited by a low $(10 \mathrm{mg} / \mathrm{kg})$, but not by a high $(20 \mathrm{mg} / \mathrm{kg})$ dose of cocaine was blocked in DARPP-32 knock-out mice. We examined the dose dependency of the effects of cocaine on GluR1 phosphorylation. A $20 \mathrm{mg} / \mathrm{kg}$ concentration of cocaine induced an approximately sevenfold increase in Ser ${ }^{845}$ phosphorylation (709 $\pm 198 \%$ of control; Fig. $6 B$ ) in wild-type mice. This increase was not significantly reduced in DARPP-32 knock-out mice $(479 \pm 165 \%$ of control; Fig. $6 B)$.

\section{Regulation of GluR1 phosphorylation by methamphetamine in vivo}

Methamphetamine-HCl, a substituted analog of D-amphetamine with profound abuse potential, also increases dopamine availability in the neostriatum. The effect of systemic injection of methamphetamine on the in vivo phosphorylation of GluR1 in mouse neostriatum was examined. Injection of mice with methamphetamine (i.e., 20 or $30 \mathrm{mg} / \mathrm{kg}$, s.c.) induced behavioral activation, eliciting intense grooming behavior and hypersensitivity to touch. Treatment of mice with methamphetamine $(20 \mathrm{mg} / \mathrm{kg}$, s.c. $)$ increased phospho-Ser ${ }^{845}$ levels by twofold to threefold in neostriatum 30 min after drug injection $(254 \pm 32 \%$ of saline-injected wild-type) (Fig. $7 B$ ). In contrast, methamphetamine treatment had no effect on the level of phospho-Ser ${ }^{831}(93 \pm 12 \%$ of saline-injected control) (Fig. 7D). This dose of methamphetamine also increased the phosphorylation of DARPP-32 on $\mathrm{Thr}^{34}$ by more than twofold in the neostriatum of mice $(270 \pm 82 \%$ of control) (Fig. $7 E$ ). The increase in phospho-Ser ${ }^{845}$ induced by this concentration of methamphetamine was fully blocked in DARPP-32 knock-out mice $(120 \pm 28 \%$ of saline-injected wild type) (Fig. $7 B$ ). A higher concentration of methamphetamine (30 $\mathrm{mg} / \mathrm{kg}$, s.c.) induced a fourfold to fivefold increase in $\mathrm{Ser}^{845}$ phosphorylation in the neostriatum of wild-type mice compared to vehicle-treated controls $(486 \pm 80 \%$ of saline-injected wild types) (Fig. 7C). The higher concentration of methamphetamine induced a significant increase in Ser $^{845}$ phosphorylation even in the DARPP-32 knock-out mice (325 $\pm 40 \%$ of saline-injected knock-out mice) (Fig. $7 C$ ). The level of $\mathrm{Ser}^{845}$ phosphorylation that was observed in the knock-out mice, however, was significantly reduced compared to wild-type mice (Fig. $7 C$ ).

$\leftarrow$

eight mice per group $\left({ }^{*} p<0.01\right.$ compared with saline-injected mice; Student's $t$ test). A, Bottom, A typical autoradiogram shows the level of phospho-DARPP-32 in a saline-injected and a cocaine-injected wild-type mouse neostriatum. The bar graph shows phospho-Thr ${ }^{34}$ DARPP-32 levels in the neostriata of mice. Data are expressed as means \pm SEM for four mice per group $\left({ }^{*} p<0.05\right.$ compared with saline-injected mice; Mann-Whitney $U$ test). $B$, Data are expressed as means \pm SEM for 3-5 mice per group $\left({ }^{*} p<0.05\right.$ compared with respective saline-injected controls; Mann-Whitney $U$ test). 


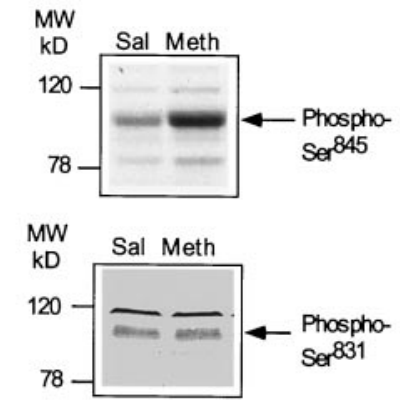

Figure 7. Effect of acute methamphetamine administration on in vivo phosphorylation of GluR1 at $\operatorname{Ser}^{845}$ and $\mathrm{Ser}^{831}$ in wild-type and DARPP-32 knock-out mice. Wild-type $(A-E)$ or DARPP-32 knock-out $(B, C)$ mice were injected with vehicle or methamphetamine (Meth) $20 \mathrm{mg} / \mathrm{kg}$ (subcutaneously) $(B, D, E)$ or $30 \mathrm{mg} / \mathrm{kg}(A, C)$ and killed by focused microwave irradiation 30 min later. Neostriatal phospho-Ser ${ }^{845}$ GluR1 $(A-C)$ and phospho-Ser ${ }^{831}$ GluR1 $(A, D)$ and phospho-Thr ${ }^{34}$ DARPP-32 $(E)$ were detected by immunoblotting and quantitated by densitometry. Data are expressed as percentage of values for saline-injected wild-type mice and represent means \pm SEM for nine $(B, C)$, three $(D)$, or eight animals $(E)$ per group $(* p<0.05$ compared with saline-injected mice; $t p<0.05$, compared with wild-type Meth alone; Students' $t$ test).

\section{A.}

C.

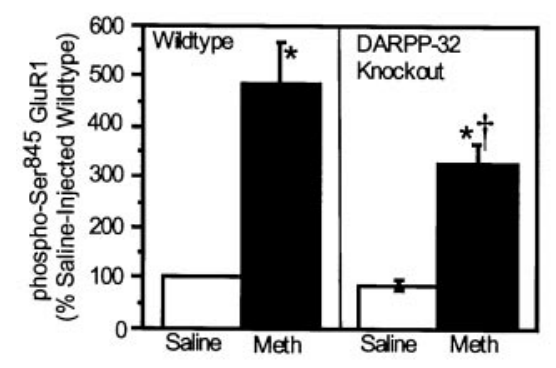

B.

D.

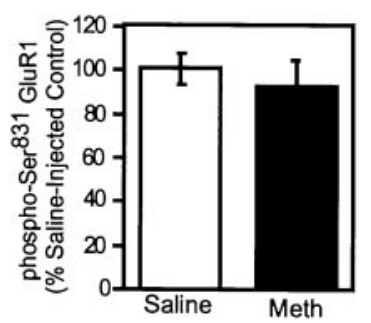

E.

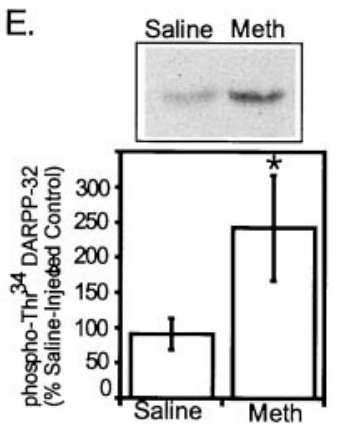

\section{DISCUSSION}

Using neostriatal slices, we have demonstrated that dopamine stimulates phosphorylation of GluR1 at Ser ${ }^{845}$ through activation of D1-type dopamine receptors and stimulation of adenylyl cyclase and PKA. We have also demonstrated that psychostimulants rapidly and reversibly increase the phosphorylation of GluR1 at $\mathrm{Ser}^{845}$ in the neostriatum in vivo. Estimates of the stoichiometry of GluR1 phosphorylation indicate that a substantial proportion of the GluR1 is phosphorylated at $\mathrm{Ser}^{845}$ in response either to dopamine in slices or to cocaine and methamphetamine in vivo. These data indicate that regulation of the state of phosphorylation of GluR1 represents a probable mechanism for control of AMPA receptor currents by dopamine and psychostimulants. Results from a previous study involving a Ser ${ }^{845}$-Ala mutation of GluR1 indicated that phosphorylation of GluR1 at Ser ${ }^{845}$ was required to potentiate peak currents carried by homomeric GluR1 receptors (Roche et al., 1996). In addition, PKA agonists reversed synaptic depression of AMPA currents in hippocampal slices by increasing phosphorylation at $\operatorname{Ser}^{845}$ (Kameyama et al., 1998; Lee et al., 1998). Taken together, these data suggest that dopamine-induced, PKA-mediated, phosphorylation of $\mathrm{Ser}^{845}$ in slices and in vivo is likely to enhance glutamatergic transmission through AMPA receptors.

AMPA receptor currents are also modulated by phosphorylation of GluR1 at Ser ${ }^{831}$ (Barria et al., 1997; Derkach et al., 1999). This residue, which is phosphorylated in vitro by PKC or CaMKII (McGlade-McCulloh et al., 1993; Blackstone et al., 1994), is also phosphorylated to a low but measurable stoichiometry in untreated neostriatum. However, the phosphorylation of this site was not regulated in response to dopaminergic activity in slices or in vivo with either wild-type mice (Fig. $2 B$ ) or in DARPP-32 knock-out mice (data not shown). The data further suggest that dopamine and D1 agonists regulate AMPA receptor currents through the selective phosphorylation of Ser ${ }^{845}$. The proportion of GluR1 subunits phosphorylated at $\mathrm{Ser}^{831}$ is greatly increased by activation of PKC (Fig. $1 B$ ) or CaMKII signaling pathways (our unpublished observations), suggesting that both $\mathrm{Ser}^{845}$ and Ser $^{831}$ can serve to mediate neurotransmitter-specific effects on AMPA receptors.

Dopamine-induced phosphorylation at $\operatorname{Ser}^{845}$ in slices and psychostimulant-induced phosphorylation of $\mathrm{Ser}^{845}$ in vivo were reduced in the neostriatum of DARPP-32 knock-out mice. These data are consistent with the loss of D1-mediated enhancement of whole-cell AMPA currents in neostriatal neurons from DARPP-32 knock-out mice (Yan et al., 1999). Taken together, the results indicate that a pathway involving PKA and DARPP32/PP1 functionally regulates AMPA receptors in basal ganglia neurons. It is unlikely that the deficits in psychostimulant action seen in the absence of DARPP-32 are attributable to a reduced ability to release dopamine. This conclusion is supported by a recent study in which dopamine overflow in neostriatum was measured by amperometry in response to stimulation of the medial forebrain bundle. Stimulation-evoked dopamine release in vivo was found to be equivalent in wild-type and DARPP-32 knock-out mice (F. Gonon, A. Fienberg, and P. Greengard, unpublished observations). In addition, deletion of the DARPP-32 gene does not significantly affect either the density of D1 receptors or their affinity for dopamine ligands (P. Svenningsson, B. Fredholm, A. Fienberg, and P. Greengard, unpublished observations). Moreover, Ser $^{845}$ phosphorylation is increased comparably in slices from wild-type and DARPP-32 knock-out mice in response either to forskolin, which induces PKA activity (G. Snyder, unpublished observations), or to drugs that inhibit PP1/PP2A activity (Fig. 4B). Together, the results indicate that the loss of GluR1 regulation is caused by a loss of ability to regulate PP1 activity.

The phosphorylation of $\operatorname{Ser}^{845}$ elicited by either cocaine or methamphetamine is blocked in DARPP-32 knock-out mice at low but not at high concentrations of these drugs. These data are consistent with previous reports (Fienberg et al., 1998, Snyder et al., 1998) showing that DARPP-32 knock-out blocks responses to low (physiological) levels of activation of transmission, but not to 
high (often supraphysiological) levels of activation. For example, cocaine-induced locomotor activation in mice induced by a 10 $\mathrm{mg} / \mathrm{kg}$ dose of drug is fully blocked in DARPP-32 knock-out mice, whereas activation induced by a $20 \mathrm{mg} / \mathrm{kg}$ cocaine injection is unaffected by DARPP-32 knock-out (Fienberg et al., 1998).

Taken together, we propose the following interpretation of these data: that PKA increases phosphorylation of $\operatorname{Ser}^{845}$ by at least two mechanisms: (1) by directly phosphorylating $\mathrm{Ser}^{845}$, and (2) by increasing phosphorylation of DARPP-32 at $\mathrm{Thr}^{34}$, leading to inhibition of PP1 activity. Thus, our data suggest that high concentrations of psychostimulants (i.e., $30 \mathrm{mg} / \mathrm{kg}$ methamphetamine or $20 \mathrm{mg} / \mathrm{kg}$ cocaine) provide sufficient activation of PKA to sustain PKA-mediated phosphorylation of GluR1 in the absence of PP1 inhibition. The results obtained at the lower concentrations of psychostimulants support a role for PKAdependent phosphorylation of DARPP-32 at $\mathrm{Thr}^{34}$ as an obligatory component of pathways that mediate a variety of biochemical, physiological, and behavioral effects of dopamine in neostriatal neurons (Fienberg et al., 1998; Greengard et al., 1999). However, a recent study (Bibb et al., 1999) has demonstrated that DARPP-32 is phosphorylated at $\mathrm{Thr}^{75}$ by a cyclin-dependent kinase family member, cdk5, converting the protein into a PKA inhibitor. It will be important in future studies to evaluate the possible contribution of the regulation of $\mathrm{Thr}^{75}$ of DARPP-32 to the control of AMPA channels by dopamine and psychostimulants.

Psychostimulants are known to regulate various biochemical indices of glutamate function including glutamate release, metabolism, and receptor expression (Wolf, 1998). Most of these changes do not occur in response to acute drug use, but appear only after repeated drug presentation, indicating that they represent indirect, long-term adaptive responses. The present results show that the regulation of AMPA receptor current through phosphorylation is likely to be a rapid, acute, and dramatic response to neostriatal dopamine release by psychostimulant drugs. The enhancement of AMPA receptor currents by these drugs represents an attractive mechanism by which glutamate receptors and their signaling pathways might be recruited to mediate a variety of effects, such as increased immediate early gene (IEG) expression (Konradi et al., 1996), which may eventually lead to sensitization. In support of this idea, AMPA or NMDA receptor antagonists block amphetamine-induced IEG expression (Konradi et al., 1996) and prevent the development of behavioral sensitization to amphetamine (Karler et al., 1989; Wolf, 1998).

\section{REFERENCES}

Allen PB, Ouimet CC, Greengard P (1997) Spinophilin, a novel protein phosphatase 1 binding protein localized to dendritic spines. Proc Natl Acad Sci USA 94:9956-9961.

Barria A, Muller D, Derkach V, Griffith LC, Soderling TR (1997) Regulatory phosphorylation of AMPA-type glutamate receptors by CaMKII during long-term potentiation. Science 276:2042-2045.

Bibb JA, Snyder GL, Nishi A, Yan Z, Meijer L, Fienberg AA, Tsai L-H, Kwon YT, Girault J-A, Czernik AJ, Huganir RL, Hemmings Jr HC, Nairn AC, Greengard P (1999) Phosphorylation of DARPP-32 by Cdk5 modulates dopamine signalling in neurons. Nature 402:669-671.

Blackstone CD, Murphy TH, Moss SJ, Baraban JM, Huganir RL (1994) Cyclic AMP and synaptic activity-dependent phosphorylation of AMPA-preferring glutamate receptors. J Neurosci 14:7585-7593.

Bliss TVP, Collingridge GL (1993) Synaptic model of memory: longterm potentiation in the hippocampus. Nature 361:31-39.

Cepeda C, Buchwald NA, Levine MS (1993) Neuromodulatory actions of dopamine in the neostriatum are dependent upon the excitatory amino acid receptor subtypes activated. Proc Natl Acad Sci USA 90:9576-9580.

Derkach V, Barria A, Soderling TR (1999) $\mathrm{Ca}^{2+} /$ calmodulin-kinase II enhances channel conductance of $\alpha$-amino-3-hydroxy-5-methyl-4isoxazolepropionate type glutamate receptors. Proc Natl Acad Sci USA 96:3269-3274.

Fienberg AA, Hiroi N, Mermelstein PG, Song W-J, Snyder GL, Nishi A, Cheramy A, O'Callaghan JP, Miller DB, Cole DG, Corbett R, Haile CN, Cooper DC, Onn S-P, Grace AA, Ouimet CC, White FJ, Hyman SE, Surmeier DJ, Girault J-A, Nestler EJ, Greengard P (1998) DARPP-32: Regulator of the efficacy of dopaminergic neurotransmission. Science 271:838-842.

Greengard P, Jen J, Nairn AC, Stevens CF (1991) Enhancement of the glutamate response by cAMP-dependent protein kinase in hippocampal neurons. Science 253:1135-1138.

Greengard P, Allen PB, Nairn AC (1999) Beyond the dopamine receptor: the DARPP-32/protein phosphatase-1 cascade. Neuron 23:435-447.

Hemmings Jr HC Greengard P, Tung HYL, Cohen P (1984) DARPP32 , a dopamine-regulated neuronal phosphoprotein, is a potent inhibitor of protein phosphatase-1. Nature 310:503-505.

Hernandez S, Day M, Surmeier DJ (1999) Activation of D2 dopamine receptors decreases L-type calcium currents in striatal medium spiny neurons. Soc Neurosci Abstr 25:1654.

Huff RM (1996) Signal transduction pathways modulated by the D2 subfamily of dopamine receptors. Cell Signal 8:453-459.

Hyman S (1996) Addiction to cocaine and amphetamine. Neuron 16:901-904

Kameyama K, Lee H-K, Bear MF, Huganir RL (1998) Involvement of a postsynaptic protein kinase A substrate in the expression of homosynaptic long-term depression. Neuron 21:1163-1175.

Karler R, Calder LD, Chaudhry IA, Turkanis SA (1989) Blockade of "reverse tolerance" to cocaine and amphetamine by MK-801. Life Sci 45:599-606.

Konradi C, Leveque J-C, Hyman SE (1996) Amphetamine and dopamine-induced immediate early gene expression in striatal neurons depends on postsynaptic NMDA receptors and calcium. J Neurosci 16:4231-4239.

Koob GF, LeMoal M (1997) Drug abuse: hedonistic homeostatic dysregulation. Science 278:52-58.

Laemmli UK (1970) Cleavage of structural proteins during the assembly of head of bacteriophage T4. Nature 227:680-685.

Lee H-K, Kameyama K, Huganir RL, Bear MF (1998) NMDA induces long-term synaptic depression and dephosphorylation of the GluR1 subunit of AMPA receptors in hippocampus. Neuron 21:1151-1162.

Linden DJ (1994) Long-term synaptic depression in the mammalian brain. Neuron 12:457-472.

Lipton SA, Rosenberg PA (1994) Mechanisms of disease: excitatory amino acids as a final common pathway for neurologic disorders. N Engl J Med 330:613-622.

Mammen AL, Kameyama K, Roche KW, Huganir RL (1997) Phosphorylation of the $\alpha$-amino-3-hydroxy-5-methylisoxazole-4-propionic acid receptor GluR1 subunit by calcium/calmodulin-dependent kinase II. J Biol Chem 272:32528-32533.

McGlade-McCulloh E, Yamamoto H, Tan S-E, Brickey DA, Soderling TR (1993) Phosphorylation and regulation of glutamate receptors by calcium/calmodulin-dependent protein kinase II. Nature 362:640-642.

Monaghan DT, Bridges RJ, Cotman CW (1989) The excitatory amino acid receptors: their classes, pharmacology, and distinct properties in the function of the nervous system. Ann Rev Pharmacol Toxicol 29:365-402.

Nestler EJ, Aghajanian GK (1997) Molecular and cellular basis of addiction. Science 278:58-63.

Ouimet CC, Miller PE, Hemmings Jr HC, Walaas SI, Greengard P (1984) DARPP-32, a dopamine- and adenosine $3^{\prime}: 5^{\prime}$-monophosphateregulated phosphoprotein enriched in dopamine-innervated brain regions. III. Immunocytochemical localization. J Neurosci 4:114-124.

Ouimet CC, da Cruz e Silva E, Greengard P (1995) The alpha and gamma 1 isoforms of protein phosphatase 1 are highly and specifically concentrated in dendritic spines. Proc Natl Acad Sci USA 92:3396-3400.

Petralia RS, Wenthold RJ (1992) Light and electron immunocytochemical localization of AMPA-selective glutamate receptors in the rat brain. J Comp Neurol 318:329-354.

Roche KW, O-Brien RJ, Mammen AL, Bernhardt J, Huganir RL (1996) 
Characterization of multiple phosphorylation sites on the AMPA receptor GluR1 subunit. Neuron 16:1179-1188.

Rosenmund C, Carr DW, Bergeson SE, Nilaver G, Scott JD, Westbrook GL (1994) Anchoring of protein kinase A is required for modulation of AMPA/kainate receptors on hippocampal neurons. Nature 368:853-856.

Sibley DR, Monsma Jr FJ (1992) Molecular biology of dopamine receptors. Trends Pharmacol Sci 13:61-69.

Snyder GL, Girault J-A, Chen JYC, Czernik AJ, Kebabian JW, Nathanson JA, Greengard P (1992) Phosphorylation of DARPP-32 and protein phosphatase inhibitor-1 in rat choroid plexus: regulation by factors other than dopamine. J Neurosci 12:3071-3083.

Snyder GL, Fienberg AA, Huganir RL, Greengard P (1998) A dopamine/D1 receptor/PKA/DARPP-32/protein phosphatase-1 pathway regulates dephosphorylation of the $N$-methyl-D-aspartate receptor J Neurosci 10297-10303.

Stoof JC, Kebabian JW (1981) Opposing roles for D-1 and D-2 dopamine receptors in efflux of cyclic AMP from rat neostriatum. Nature 294:366-368.
Tan SE, Wenthold RJ, Soderling TR (1994) Phosphorylation of AMPAtype glutamate receptors by calcium/calmodulin-dependent protein kinase II and protein kinase $\mathrm{C}$ in cultured hippocampal neurons. J Neurosci 14:1123-1129.

Towbin H, Staehlin T, Gordon J (1979) Electrophoretic transfer of proteins from polyacrylamide gels to nitrocellulose sheets: procedure and some applications. Proc Natl Acad Sci USA 76:4350-4354.

Walaas SI, Aswad DW, Greengard P (1983) A dopamine- and cyclic AMP-regulated phosphoprotein enriched in dopamine-innervated brain regions. Nature 301:69-71.

Wang LY, Salter MW, McDonald JF (1991) Regulation of kainate receptors by cAMP-dependent protein kinase and phosphatases. Science 253:1132-1135.

Wolf ME (1998) The role of excitatory amino acids in behavioral sensitization to psychomotor stimulants. Prog Neurobiol 54:679-720.

Yan Z, Hsieh-Wilson L, Feng J, Tomizawa K, Allen PB, Fienberg AA, Nairn AC, Greengard P (1999) Protein phosphatase 1 modulation of neostriatal AMPA channels: regulation by DARPP-32 and spinophilin. Nat Neurosci 2:13-17. 